Supporting Information

\title{
Mechanistic study of radium adsorption onto goethite
}

\author{
Qiantao Shi ${ }^{1}$, Xiaoguang Meng ${ }^{1}$, and Valentina Prigiobbe ${ }^{1,2, *}$ \\ ${ }^{1}$ Department of Civil, Environmental, and Ocean Engineering, \\ ${ }^{2}$ Department of Chemical Engineering and Material Science, \\ Stevens Institute of Technology, 07030, Hoboken (NJ) U.S.A. \\ ${ }^{*}$ Corresponding author: Valentina Prigiobbe. E-mail: \\ valentina.prigiobbe@stevens.edu. Phone: +1-201-216-5310.
}

Number of Pages: 8

Number of Figures: 6

Number of Tables: 1 


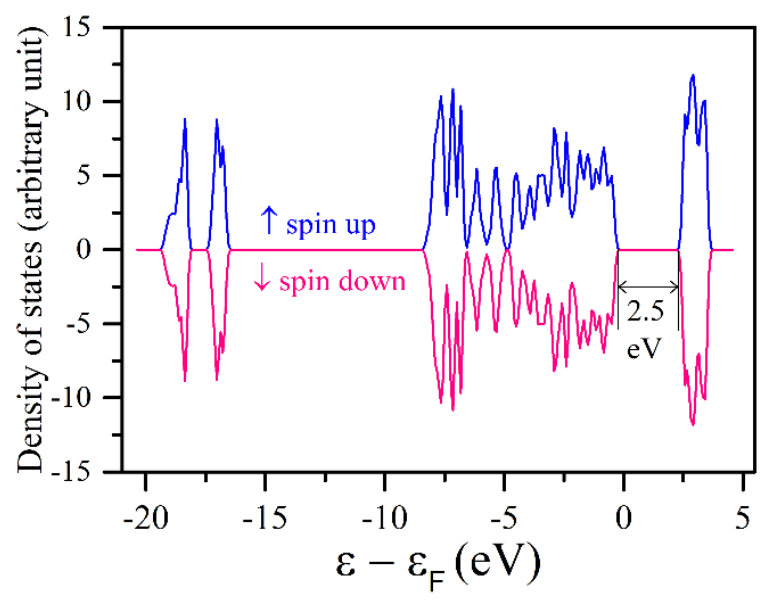

Figure S1. Density of states calculated by GGA+U functions, corresponding to a band gap of $2.5 \mathrm{eV}$. 


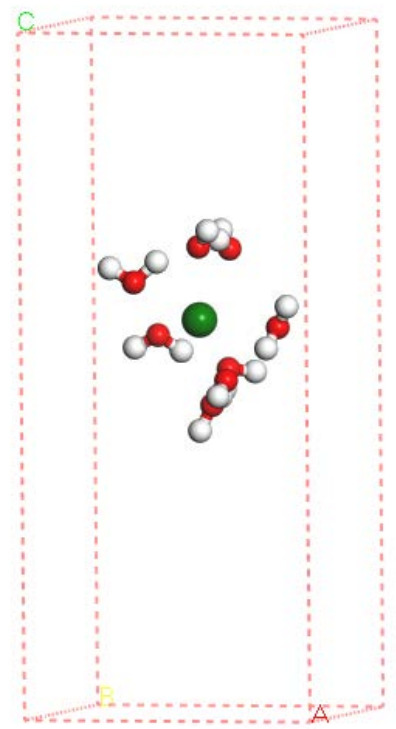

Figure S2. Hydration of $\mathrm{Ra}^{2+}$ with two hydroxyls and six water molecules calculated in a cell with the same dimensions as the cell used for the goethite surfaces. The interatomic distances between Ra and oxygen atoms ranged from 2.764 to $3.033 \AA$. 

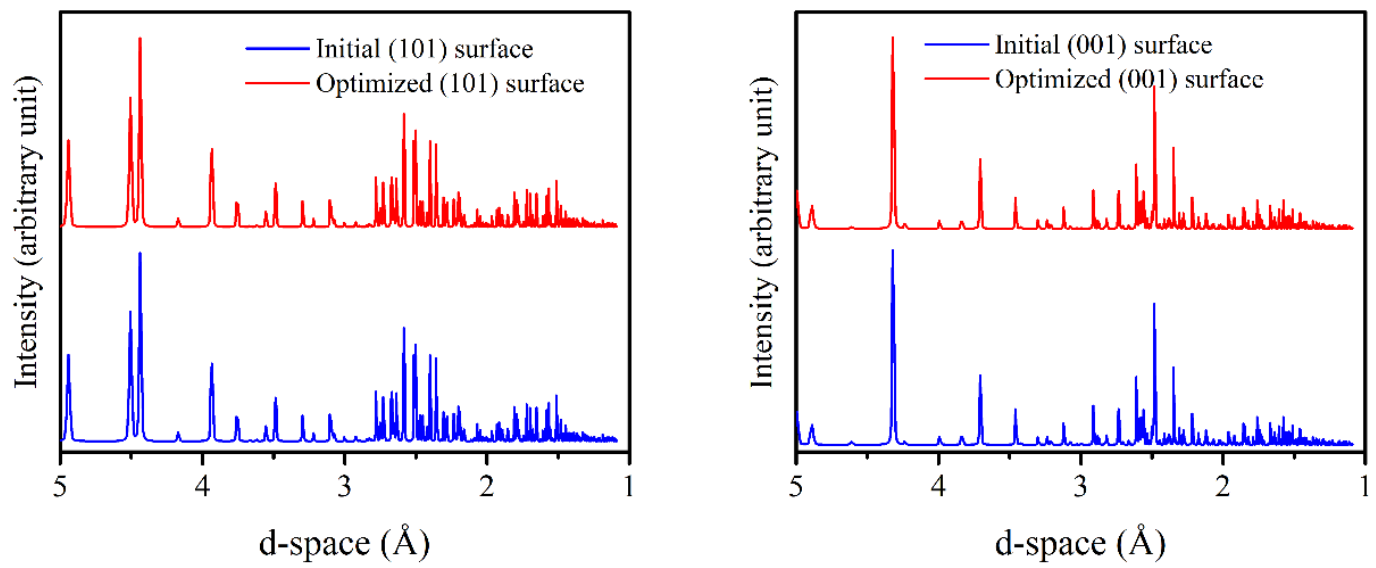

Figure S3. Interplanar spacing of (101) and (001) surface cells. Please note that, those values are different from goethite unicell because of the presence of a $12 \AA$ vacuum layer.

The interplanar spacing (d-space) for initial and optimized (101) and (001) surfaces were also compared. As shown in Figure S3, no significant difference between the initial and optimized surfaces was observed, suggesting that the d-space of optimized (101) and (001) surfaces is as same as the initial structure (bulk derived structure). Therefore, the surface thickness is enough for this study. 


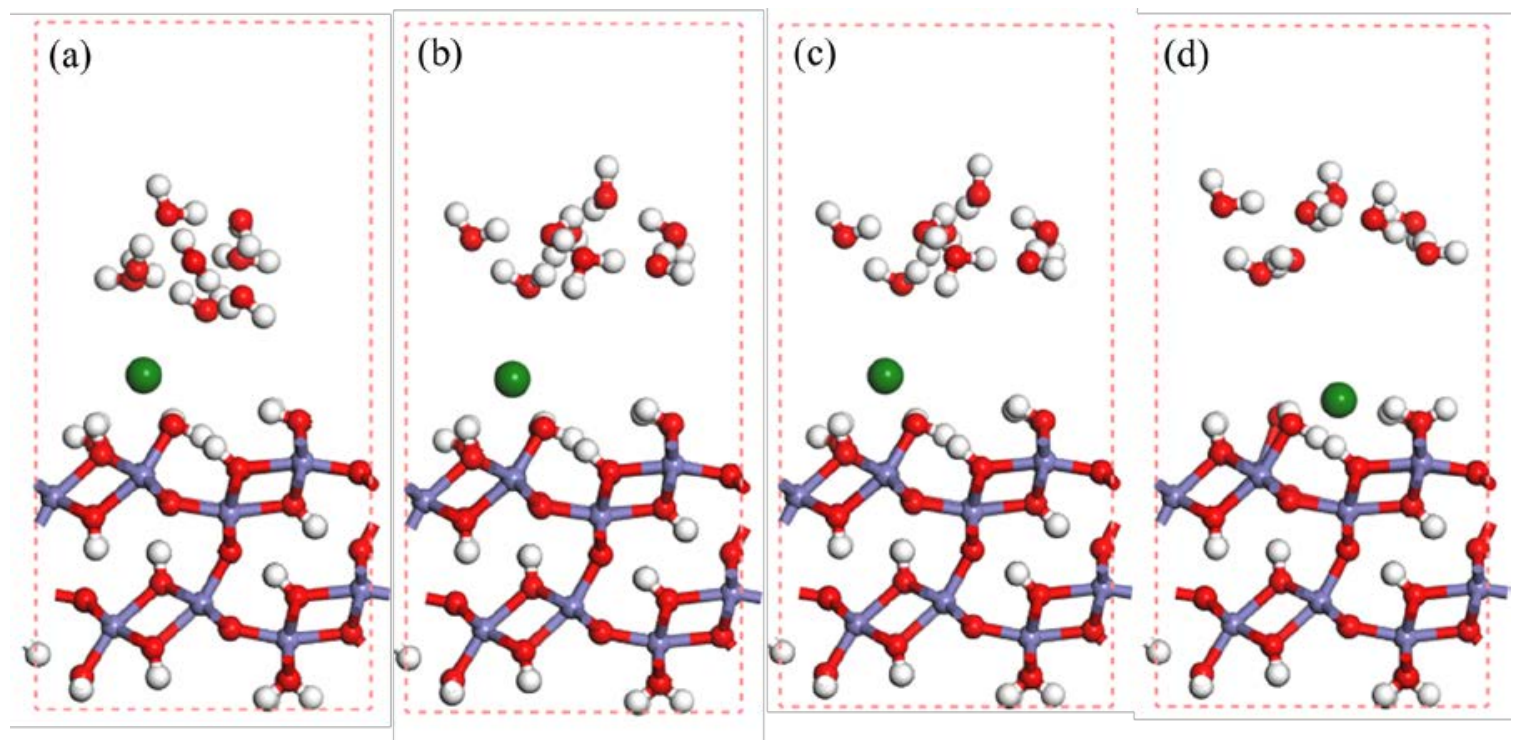

Figure S4. Side view of optimized adsorption structures for $\mathrm{Ra}^{2+}$ on (101) crystalline surface of goethite, considering: (a) monodentate inner-sphere, (b) bidentate inner-sphere, (c) tridentate inner-sphere, and (d) tetradentate inner-sphere. Note: Water molecules were maintained in the vacuum gap for comparison with outer-sphere adsorption models. 


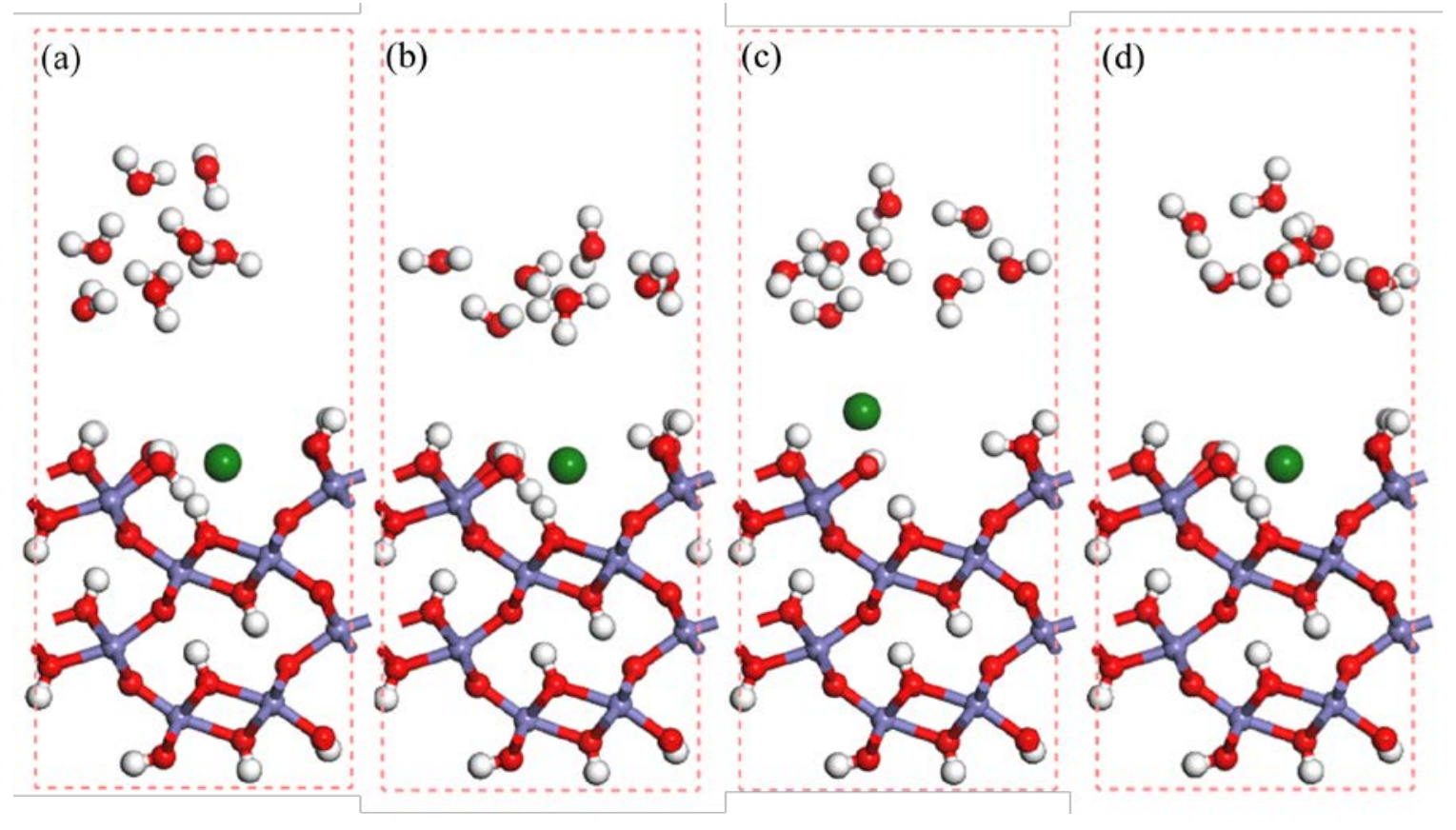

Figure S5. Side view of optimized adsorption structures for $\mathrm{Ra}^{2+}$ on (001) crystalline surface of goethite, considering: (a) monodentate inner-sphere, (b) bidentate inner-sphere, (c) tridentate innersphere, and (d) tetradentate inner-sphere. Note: Water molecules were maintained in the vacuum gap for comparison with outer-sphere adsorption models. 
Table S1. Surface complexation modeling parameters and species for $\mathrm{Ra}^{2+}$ adsorption onto goethite.

\begin{tabular}{|c|c|c|c|c|c|c|}
\hline Description & Chemical reaction & $\Delta \mathrm{z}_{0}^{*}$ & $\Delta \mathrm{zb}_{\mathrm{b}}^{*}$ & $\Delta \mathrm{zd}_{\mathrm{d}}^{*}$ & LogK & Sources \\
\hline $\begin{array}{c}\text { Outer-sphere } \\
\text { adsorption of } \mathrm{Ra}^{2+}\end{array}$ & $\begin{array}{l}\equiv \mathrm{FeO}^{-1 / 2}+\mathrm{Ra}^{2+}= \\
\equiv \mathrm{FeO}^{-1 / 2} \cdots \cdots \cdot \mathrm{Ra}^{2+}\end{array}$ & & \multicolumn{2}{|r|}{2} & 3.9 & \multirow{4}{*}{$\begin{array}{l}\text { Fitting } \\
\text { in this } \\
\text { study }\end{array}$} \\
\hline $\begin{array}{c}\text { Inner-sphere } \\
\text { tridentate } \\
\text { adsorption of } \mathrm{Ra}^{2+}\end{array}$ & $\begin{array}{c}3 \equiv \mathrm{FeO}^{-1 / 2}+\mathrm{Ra}^{2+}= \\
(\equiv \mathrm{FeOH})_{3} \mathrm{Ra}^{1 / 2}\end{array}$ & 0.5 & 1.5 & & 3.5 & \\
\hline $\begin{array}{c}\text { Inner-sphere } \\
\text { pentadentate } \\
\text { adsorption of } \mathrm{Ra}^{2+}\end{array}$ & $\begin{array}{c}5 \equiv \mathrm{FeO}^{-1 / 2}+\mathrm{Ra}^{2+}= \\
(\equiv \mathrm{FeOH})_{5} \mathrm{Ra}^{-1 / 2}\end{array}$ & 0.5 & 1.5 & & 3.6 & \\
\hline $\begin{array}{l}\text { Protonation of } \\
\text { adsorption sites }\end{array}$ & $\begin{array}{c}\equiv \mathrm{FeO}^{-1 / 2}+\mathrm{H}^{+}= \\
\equiv \mathrm{FeOH}^{1 / 2}\end{array}$ & 1 & & & 7.3 & \\
\hline $\begin{array}{c}\text { Outer-sphere } \\
\text { adsorption of } \mathrm{Na}^{+}\end{array}$ & $\begin{array}{l}\equiv \mathrm{FeO}^{-1 / 2}+\mathrm{Na}^{+}= \\
\equiv \mathrm{FeO}^{-1 / 2} \cdots \cdots \mathrm{Na}^{+}\end{array}$ & & & 1 & -1 & Ref. $^{1}$ \\
\hline $\begin{array}{c}\text { Outer-sphere } \\
\text { adsorption of } \mathrm{Cl}^{-}\end{array}$ & $\begin{aligned} \equiv & \mathrm{FeO}^{-1 / 2}+\mathrm{H}^{+}+\mathrm{Cl}^{-}= \\
& \equiv \mathrm{FeOH}^{+1 / 2} \cdots \cdots \mathrm{Cl}^{-}\end{aligned}$ & 1 & & -1 & 6.3 & Ref. ${ }^{1}$ \\
\hline \multirow{2}{*}{\multicolumn{2}{|c|}{$\begin{array}{l}\text { Inner-sphere capacitance } C_{1}\left(\mathrm{~F} / \mathrm{m}^{2}\right) \\
\text { Outer-sphere capacitance } C_{2}\left(\mathrm{~F} / \mathrm{m}^{2}\right)\end{array}$}} & \multicolumn{4}{|c|}{0.9} & \multirow{2}{*}{$\begin{array}{l}\text { Fitting in } \\
\text { this study }\end{array}$} \\
\hline & & & & .2 & & \\
\hline \multicolumn{2}{|c|}{ Surface area $\left(\mathrm{m}^{2} / \mathrm{g}\right)^{* *}$} & \multicolumn{4}{|c|}{146 and 23.6} & \\
\hline \multicolumn{2}{|c|}{ Site density $\left(\text { sites } / \mathrm{nm}^{2}\right)^{* *}$} & \multicolumn{4}{|c|}{1.8} & Ref. ${ }^{2,3}$ \\
\hline \multicolumn{2}{|c|}{ Adsorbent concentration (g/L)** } & \multicolumn{4}{|c|}{0.3 and 10} & \\
\hline
\end{tabular}

* The change of charge in the 0-, b-, and d-planes, respectively.

$* *$ The site density of 1.8 sites $/ \mathrm{nm}^{2}$ is the average of the values used in the studies by Ref. 2 and 3, whereas the surface area and adsorbent concentration are the experimental values in Ref. 2 and 3. 


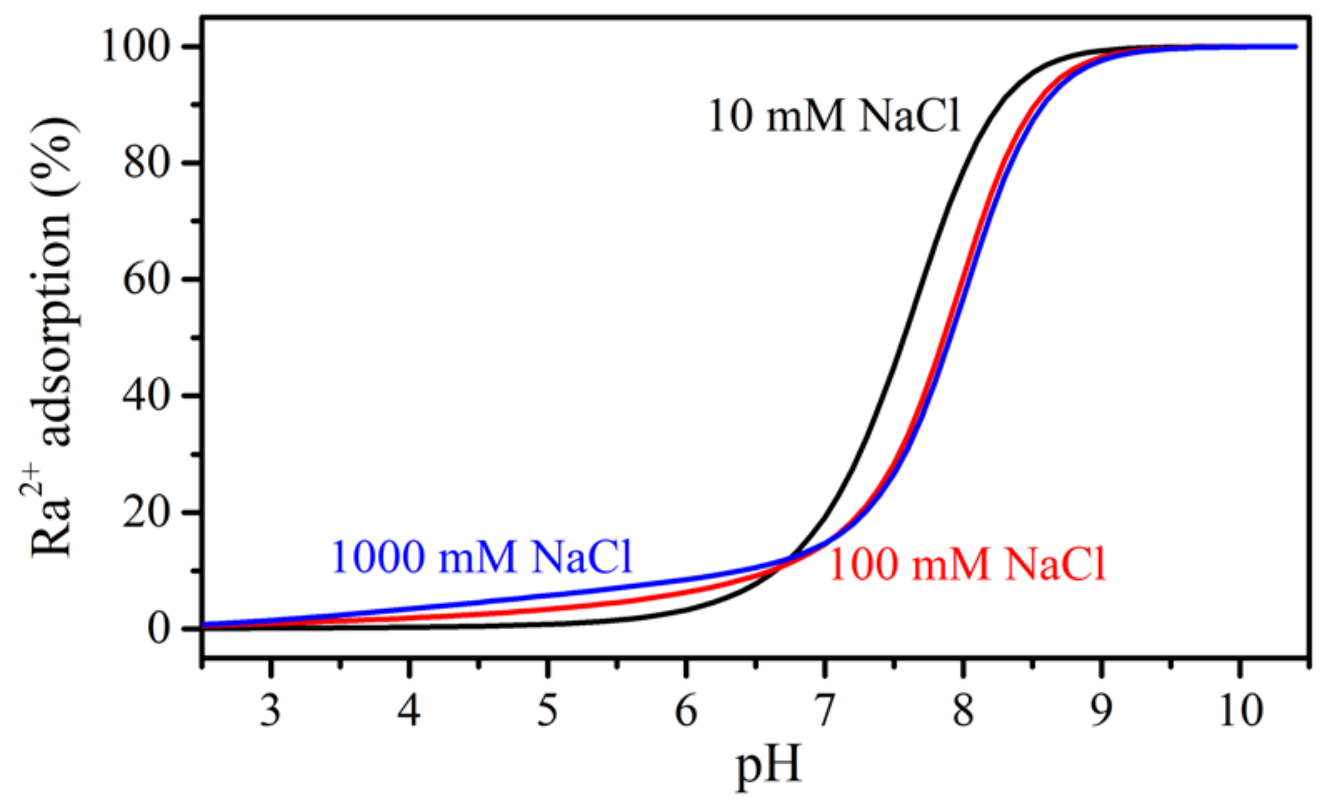

Figure S6. $\mathrm{Ra}^{2+}$ concentration adsorbed on goethite as a function of $\mathrm{pH}$ in solutions containing different $\mathrm{NaCl}$ concentration. Parameters: goethite concertation of $0.3 \mathrm{~g} / \mathrm{L}$, specific surface area equal to 146 $\mathrm{m}^{2} / \mathrm{g}$, and initial $\mathrm{Ra}^{2+}$ concentration equal to $0.4 \mathrm{nM}$.

\section{References:}

(1) Hiemstra, T.; Van Riemsdijk, W. H., A surface structural approach to ion adsorption: the charge distribution (CD) model. Journal of Colloid and Interface Science 1996, 179, 488-508.

(2) Chen, M. A.; Kocar, B. D., Radium Sorption to Iron (Hydr)oxides, Pyrite, and Montmorillonite: Implications for Mobility. Environmental Science \& Technology 2018, 52, 4023-4030.

(3) Sajih, M.; Bryan, N. D.; Livens, F. R.; Vaughan, D. J.; Descostes, M.; Phrommavanh, V.; Nos, J.; Morris, K., Adsorption of radium and barium on goethite and ferrihydrite: A kinetic and surface complexation modelling study. Geochim Cosmochim Ac 2014, 146, 150-163. 